$$
\begin{aligned}
& \text { H.C. } \$ 1.00 \text {, wn. } 50 \\
& \text { PFP-765 } \\
& \text { Conf-660518-1 }
\end{aligned}
$$

RELEASED FOR ANNOUNCEMENT

IN NUCLEAR SCIENCE ABSTRACTS

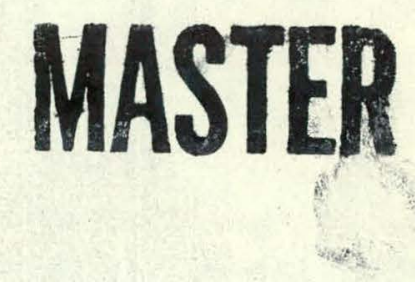

\title{
ELECTRON MICROPROBE ANALYSIS OF PLUTONIUM- GALLIUM ALLOYS
}

\section{by}

\author{
M. R. Harvey and D. H. Riefenberg
}

This talk is to be presented at the 20th AEC Annual Metallography Meeting to be held at the Brown Palace Hotel, Denver, Colorado, May $18-20,1966$.

\section{LEGAL NOTICE}

This report was prepared as an account of Government sponsured wurk, Neillies the Unlled States, nor the Commission, nor any persuu acting on behalf of the Commission:

A. Makes any warranty or representation, expressed or implied, with respect to the accuracy, completeness, or usefulness of the information contained in this report, or that the use of any information, apparatus, method, or process disclosed in this report may not infringe privately owned rights; or

B. Assumes any liabilities with respect to the use of, or for damages resulting from the use of any information, apparatus, method, or process disclused in this report.

As used in the above, "person acting on behalf of the Commission" includes any employee or contractor of the Commission, or employee of such contractor, to the extent that such employee or contractor of the Commission, or employee of such contractor prepares disseminates, or provides access to, any information pursuant to his employment or contract

with the Commiseion, or his emplnyment with surh rentrartor. 


\section{DISCLAIMER}

This report was prepared as an account of work sponsored by an agency of the United States Government. Neither the United States Government nor any agency Thereof, nor any of their employees, makes any warranty, express or implied, or assumes any legal liability or responsibility for the accuracy, completeness, or usefulness of any information, apparatus, product, or process disclosed, or represents that its use would not infringe privately owned rights. Reference herein to any specific commercial product, process, or service by trade name, trademark, manufacturer, or otherwise does not necessarily constitute or imply its endorsement, recommendation, or favoring by the United States Government or any agency thereof. The views and opinions of authors expressed herein do not necessarily state or reflect those of the United States Government or any agency thereof. 


\section{DISCLAIMER}

Portions of this document may be illegible in electronic image products. Images are produced from the best available original document. 


\begin{abstract}
Electron Microprobe Analysis of PlutontumGallium Alloys
\end{abstract}

By

M. R. Harvey \& D. Riefenberg

A calibration curve of relative intensity versus gallium concentration was obtained on a series of plutonium-gallium alloys. The concentration range studied was 0.56 to $2.12 \mathrm{w} / \mathrm{o}$. The relative intensity was found to vary linearly with concentration in this range. Based on the standard deviations observed in this work, 19 determinations were required for an accuracy of $\pm 0.05 \mathrm{w} / \mathrm{o}$ absolute at a confldence level of $99 \%$.

REVIEWED FOR CLASSIFICAYIONG

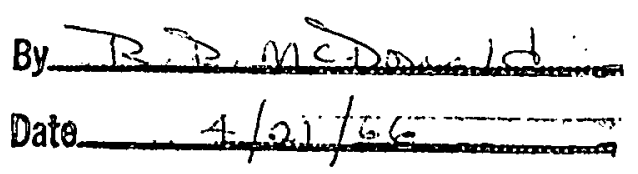


ELECTRON MICROPROBE ANALYSIS OF PLUTONIUM-GALLIUM ALLOYS

By

M. R. Harvey and D. Rlefenberg

The electron microanalyzer has the unique capability of elemental analysis of areas approximating one micron in diameter. As a result it can be extremely useful in identifying unknown inclusions and preclpitates, in studying diffusion down grain boundaries and, in determining microsegregation. Before quantitative results can be obtained however, the relationship between the relative intensities of the $\mathrm{X}$-rays generated in a sample and the concentration of the element being analyzed must be obtained. One method is to determine this relationship from a series of known homogeneous alloys, 1.e., obtain a calibration curve. In many systems however, homogeneous alloys cannot be made. Corrections due to fluorescence, atomic number, and absorption must be applied to the $\mathrm{X}$-ray intensities. An excellent discussion of these is given by ziebold ${ }^{1}$.

Of the two methods, the calibration curve is the most accurate. A variation of this method has been proposed in another pape' by Zlebold ${ }^{2}$, in which only one known alloy is needed to convert intensity data into concentrations. He proposes the following relationship of' Castaing 's 3

$$
\frac{1-K}{K}=\alpha \frac{1-C}{C}
$$

with the following important differences. 
Ziebold defines $K$ as the rat10^ $\mathrm{X}$-ray intensities, seen by the spectrometer, of an alloy to that of an elemental standard. Castaing's definition was based on the intensity generated in the sample. Originally a was defined in terms of a single correction factor, but Ziebold includes all three corrections, 1.e., fluorescence, etc. in it. The term $C$ remains unchanged being defined as the welght fraction of the alloy belng analyzed.

Zlebold's procedure consisted assuming $\alpha$ to be constant and determining it from a known alloy. It was then applied to the entire concentration range in determining unknown compositions. Hakklla, et $a 1^{4}$, applied Zlebold's equation to a $\mathrm{Pu}-1 \mathrm{w} / \mathrm{O} \mathrm{Ga}$ alloy and from this standard determined $\alpha$ to be 0.33 . Next he assumed a linear relationship between the relative intensity $K$, and the concentration $\mathrm{C}$

$$
K=\beta C
$$

for concentrations of less than $1.5 \mathrm{w} / 0$ gallium. The slope $\beta$ was determined from the $\mathrm{Pu}-1.0 \mathrm{w} / \mathrm{O}$ Ga standard. In calculating concentrations, from intensity data from two different areas of a cored Pu-Ga alloy with Zlebold's formula and his (Hakkila's), the same results were obtained.

It should be noted here that this result was not unexpected because it is easily seen that equation (1). when written in the form

$$
K=\frac{c-}{\alpha+C-\alpha C}
$$


can be approximated by

$$
\mathrm{K}=\frac{\mathrm{C}}{\alpha}
$$

for $c<1.5 \mathrm{w} / 0$

This paper extends Hakkila's work to the entire solid solution range of $\delta$ - stabilized plutonium, 1.e., $2.5 \mathrm{a} / \mathrm{o}-8.0 \mathrm{a} / \mathrm{o}$ or $.74 \mathrm{w} / \mathrm{o}-2.47 \mathrm{w} / \mathrm{o}$, in an attempt to become better acquainted with the microprobe problems involved in working with plutoniumgallium alloys, to establish the accuracy of analysis of gallium In plutonium, and to determine the reproducibility of the constant $\alpha$.

\section{EXPERIMENTAL PROCEDURE}

Plutonium with a reported heavy metal impurity of less than 100 ppm was alloyed with gallium. The metals were melted at $1000^{\circ} \mathrm{C}$ in an induction furnace and cast into $\frac{1}{2}$ " diameter rods. Samples were cut and annealed at $600^{\circ} \mathrm{C}$ for 100 hours and then at $475^{\circ} \mathrm{C}$ for 144 hours. Two gallium chemical analyses were taken on each sample. The maximum deviation between any two analyses was 0.03. w/o absolute. After mounting, sample \#'s 3, 4, 5, and 6 were mechanically polished utilizing standard techniques, ending

up with $I_{\mu}$ diamond paste. Samples 1 and 2 were polished with 600 grit paper and then chemically polished. 
In order to avold contamination of the microprobe, the samples were ultrasonically cleaned in Dow Chlorothane $\mathrm{Nu}^{*}$ and washed with ethyl alcohol. A flim of Kodacel A-30I was placed over the plutonium surface, flooded with alcohol and stripped off. The plutonlum was then masked off and clear lacquer sprayed over the entire mount. The masking was removed and the sample placed in a Materials Analysis Corporation Microprobe Model $400^{\#}$.

In order to eliminate interference from the second order $L_{\beta I}$ and $L_{\beta 3}$ plutonlum lines, an accelerating potential of $19 \mathrm{KV}$ was used. Specimen current was maintained at $0.04 \mu \mathrm{a}$ while counting. The intensities of twenty areas were determined for a 30 second interval at $1.300 \AA$ and $1.380 \AA$ for background and at 1.342A for the Ga $\mathrm{Ka}$. The counts per sec were evaluated by

$$
\text { Counts/Sec }=\frac{N_{1,342}-\left(N_{1}, 380+N_{1,300}\right)}{60}
$$

where $N_{1,342}, N_{1}, 380$, and $N_{1}, 300$ are the number of counts at the designated wavelengths. The gallium standards were evaluated in the same manner as the alloys.

* Dow Chemlcal Company, Midland, Michigan tEastman Kodak Company, Rochester, New York \#Materials Analysis Company, Palo Alto, California 
RESULTS AND DISCUSSION

Table 1 lists the intensity data of the six alloys plus the gallium standards. The relative intensities $K$ (averaged from the 20 areas), and the corresponding constants a (calculated from equation 1), are also shown.

The observed standard deviation, based on the total number of counts, for samples 1 and 6, were calculated to be 105 and 111 counts as compared to an expected deviation of 101 and 104. The sample size required for a 99\% confidence limit of a $\pm 0.05 \mathrm{w} / \mathrm{o}$ absolute deviation from the true concentration was determined to be 19.

Equation $I$ is plotted in Figure $I$ for a value of $\bar{\alpha}=0.52$. It is observed that there is a good correlation between the data and the functional relationship noted in Equation 1. Note also that the plotted function is linear in the concentration range studied which confirms Hakkila's assumption of linearity, 1.e., a single standard in this solid solution range establishes the approximate calibration curve for that region.

The calculated value of $\alpha$ is somewhat surprising. Valucs less than 1 are usually indicative of large fluorescence effects ${ }^{2}$. scott ${ }^{5}$ reports, however, that the absorption correction should be dominant in the case of Pu-Fe alloy which might be expected to exhiblt the same behavior as Pu-Ga alloys. A theoretical 
calculation of $\alpha$ was made based on a method proposed by Ziebold? yielding $\alpha=0.77$ as compared to an experimentally determined value of 0.55 . It is obvious that the use of $\alpha=0.77 \mathrm{will}$ result in an unacceptable error in C. It should not be assumed, however, that Hakk1la's measured value and the author's are in disagreement. There is apparently another correction factor in' the Pu-Ga system which cannot be predicted. In all alloys studied there was an unusually high background from $1,200 \AA$ to $1,500 \AA$ which bracketed the Ga-Ka peak. This background was traced to the plutonium. Waterbury ${ }^{6}$ stated that high background was not observed in Hakkila's study. This would effectively increase his observed $K$ value for corresponding concentrations which would account for his lower value of $\alpha$.

\section{CONCLUSIONS}

1. The electron microanalyzer is a quick, accurate tool for analyzing small amounts of gallium in plutonium.

2. The relative $\mathrm{X}$-ray intensity versus elemental concentration curve for the delta stabilized region may be approximated by a straight line thru the origin with a slope of $\frac{1}{a}$.

3. Accuracies of $\pm 0.05 \mathrm{w} / \mathrm{o}$ can be obtained with a sample size of 19.

4. A calibration curve of relative intensity versus concentration is the only acceptable way of obtalning accurate gallium analyses with the microprobe. 
TABLE 1

Relative Intensity Data for Plutonium-Gallium Alloys

\begin{tabular}{|c|c|c|c|c|c|c|}
\hline$\underset{\#}{\text { Sample }}$ & $\mathrm{w} / \mathrm{OGa}$ & $\mathrm{a} / \mathrm{OGa}$ & $\begin{array}{l}\text { Intensity } \\
\text { (Count/Sec) }\end{array}$ & $\mathrm{K}$ & $\alpha$ & Comments \\
\hline 1 & 0.56 & 1.90 & $\overline{22.4^{*}}$ & $1.07 \times 10^{-2}$ & 0.52 & *Average of 20 areas \\
\hline 2 & 0.76 & 2.57 & 31.5 & $1.50 \times 10^{-2}$ & 0.50 & $"$ \\
\hline 3 & 1.15 & 3.86 & 44.4 & $2.15 \times 10^{-2}$ & 0.53 & $" 1$ \\
\hline 4 & 1.53 & 5.07 & 60.8 & $2.95 \times 10^{-2}$ & 0.51 & 11. \\
\hline 5 & 1.85 & 6.08 & 64.1 & $3.45 \times 10^{-2}$ & 0.53 & $n$ \\
\hline 6 & 2.12 & 6.90 & 73.8 & $3.97 \times 10^{-2}$ & 0.52 & $"$ \\
\hline Sa std 1 & 100.00 & & $\overline{2096 . *}$ & & & $\begin{array}{l}\text { Used with \#'s } 1 \& 2 . \\
\text { Average of } 20 \text { areas }\end{array}$ \\
\hline Ga std 2 & 100.00 & & $\overline{2062}$ & & . & $\begin{array}{l}\text { Used with \#'s } 3 \& 4 . \\
\text { Average of } 20 \text { areas }\end{array}$ \\
\hline Ga std 3 & 100.00 & & 1858 & $\therefore$ & & $\begin{array}{l}\text { Used with \#'s } 5 \text { \& } 6 . \\
\text { Average of } 20 \text { areas }\end{array}$ \\
\hline
\end{tabular}

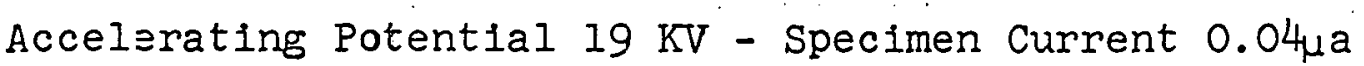




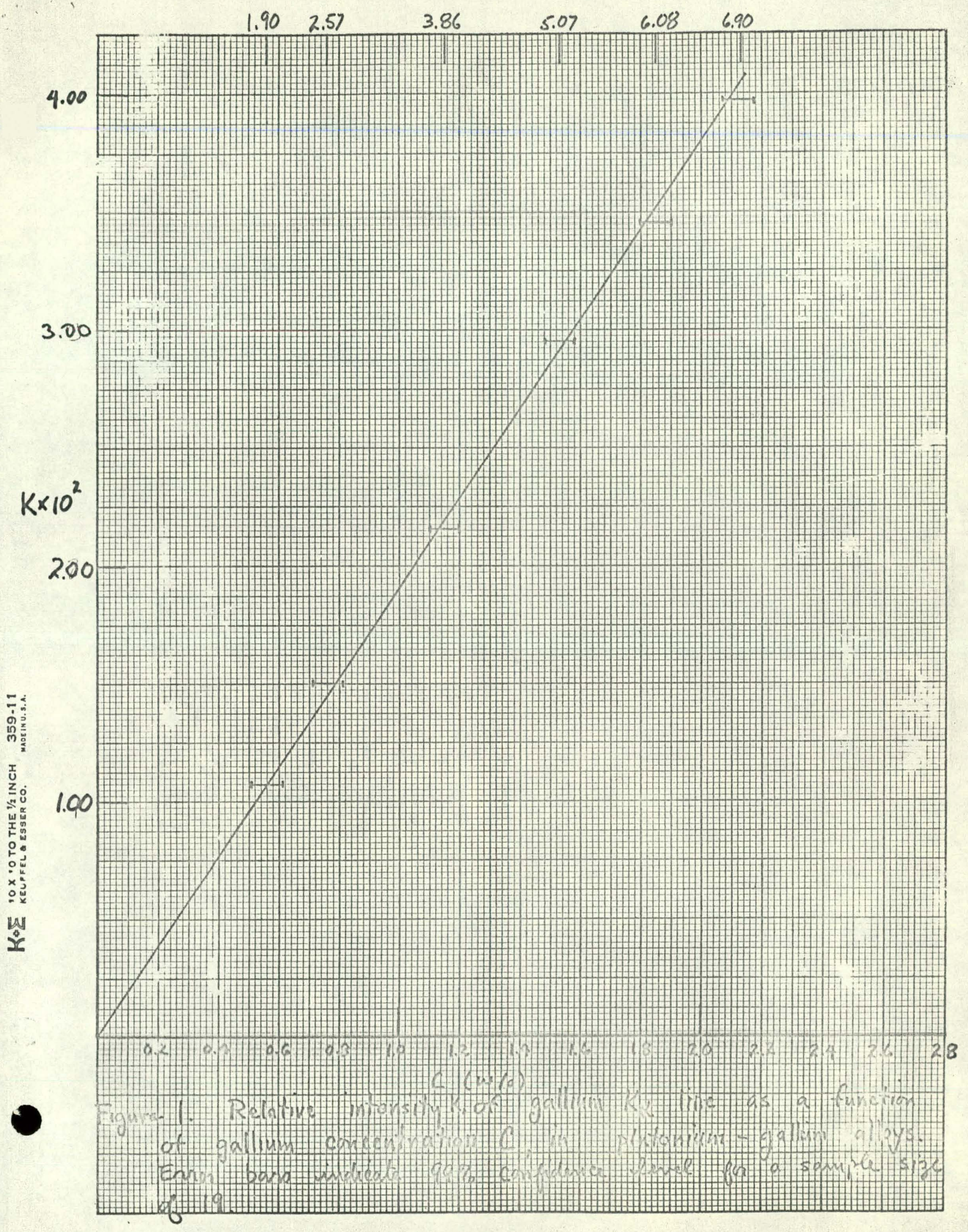


KE'E'EEINCE'S

1. T. O. Zlebold and R. E. Ogilvie, "Quantitative Analysis with the Electron Microanalyzer", Analyt. Chem., 35 $621-627$ (1963)

2. T. O. Ziebold and R. E. Ogilvie, "An Emperical Method for Electron Microanalysis", Analyt. Chem., 36 322-327 (1964)

3. R. Castaing, "Application of Electron Probes to Local Chemical and Crystallographic Analysis", thesis, University of Paris, (1951)

4. E. A. Hakkila, G. R. Waterbury, and C. F. Metz, "Electron Microprobe Examination of Delta-Stabilized Plutonium", Los Alamos Scientific Laboratory Report LA-3125, 13 p (1964)

5. V. D. Scott and G. V. T. Ranzetta, "Electron-Probe Microanalysis of Radioactive Samples (Quantitative Analyses of the Plutonium-Iron System)", J. Inst. Met., 90 160-167 $(1961-62)$

6. G. R. Waterbury, Los Alamos Scientific Laboratory, private communication 